Indian Journal of Science and Technology

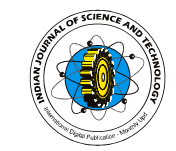

\title{
The relationship between the religious beliefs and the feeling of loneliness in elderly
}

\author{
Farzaneh Sheikholeslami ${ }^{1}$, Shadman Reza Masole ${ }^{1}$, Pantea Rafati ${ }^{2}$, Safar Ali Esmaeili Vardanjani ${ }^{3}$, \\ Mohammad Ali Yazdani Talami ${ }^{1}$ and Naima Khodadadi ${ }^{1}$ \\ ${ }^{1}$ Nursing and Midwifery Faculty, Guilan University of Medical Sciences, Guilan, Iran \\ ${ }^{2}$ Ms in Nursing Education \\ ${ }^{3}$ Nursing Education, Shahrekord University of Medical Sciences, Shahrekord, Iran
}

safaraliesmaili@yahoo.com*

\begin{abstract}
The objective of this research is to study the relationship between the religious beliefs and the feeling of loneliness in elderly. In this descriptive correlation study, the statistical society included 100 individuals of the society of retired people in the Medical University of Gilan province in Iran. The sample was taken by the easy random method. The method of collecting data was the questionnaire contained 3 parts: 1) personal characteristics and social characteristics. 2) Allport's internal and external religious beliefs scale and 3) the Standard loneliness feeling of You care. Data was analyzed by means of the description and presumption statistical methods and use of the SPSS software. The findings showed that there is a meaningful correlation between the external religious beliefs and the marital status, the amount of income, socialization with family members and relatives, social activities and also between the internal religious beliefs and the attending in the religious gatherings, the emotional support of the family, friends, and the others and the general satisfaction of the mentioned supports with $P<0.05$ and finally with the use of the nonparametric testes, a meaningful relationship has been found between the religious beliefs and the feeling of loneliness with $\mathrm{P}<0.001$. Thus this study shows that the religious believes as an important source of support in aged people, can help them to be healthier physically and psychologically and it is essential to consider it for the mental health educational plans.
\end{abstract}

Keywords: Relationship, Religious beliefs, Loneliness feeling, Elderly.

\section{Introduction}

The world population is getting older. It is predicted that the two third of people above 65 years old will be in developing countries by 2025 (Conception, 2004). In Iran, according to the survey in 1996, 6.5 percent of total populations were above 60 years old and it's predicted that this number will increase 10 percent by 2021 and in 2025 the population of elderly in Iran will reach to more than 26 million. Elderly is the years of passing precious experiences, enjoying savings, thinking about memories and reviewing the experiences which come with a unique pleasure but its perspective is not always like that. Society changes and problems and also physical and mental difficulties affect the old people. That makes elderly threatening is neither illness nor even poverty but also it is loneliness and may be this loneliness feeling is even the important factor in appearing or reinforcing the other elderly diseases (Kagagn, 2003). Loneliness feeling, isolation and hopelessness are the one of the most important and common complaints in aged people and it will affect $12-40 \%$ of the total population of above 65 years old. This feeling will intensify the physical discomforts and endanger the people's mental coherence and increase the risk of suicide. Mental problems in elderly are various and about $15-25 \%$ of the aged people has serious mental problems. Depression, anxiety and suicide are the problems which seniors are suffering (Hellstrom et al., 2004). Considering the increase of old population and the prevalence of mental disorders, the importance of having different sources to encounter with elderly conditions is the feelings. Among the methods, religion probably play an important role and it can have an effect on reducing the disorders, making the life and even death meaningful (Fealy, 2006). In attention to this important fact, the aim of this study is to recognize the effect of the religious beliefs (internal and external) on the loneliness feeling in elderly in the society of Rasht Medical University in Iran.

\section{Main Objective}

Determining the correlation between religious believes and loneliness feeling in elderly at the Retired's Society of Gilan Medical University in Iran.

Special objectives: 1) Determining the relationship between the religious believes and the demographic characteristics in senior members in the society of Gilan Medical University. 2) Determining the relationship between the loneliness feeling and the demographic characteristics in senior members in the society of Gilan Medical University. 3) Determining the relationship between the religious believes and loneliness feeling in the senior members of the society of Gilan Medical University.

Methods

This research is a descriptive-correlation study. Study setting was the society of the retired seniors of Gilan Medical University in province of Rasht in Iran and the study population was all the seniors above 60 years old in the society of Gilan Medical University which 100 of them
Popular article

CIndian Society for Education and Environment (iSee)
"Religion as a tool to overcome the feeling of loneliness in elderly" http://www.indjst.org
F.Sheikholeslami Indian J.Sci.Technol. 
Table 1.Frequency distribution and the relationship between personal characteristics and the loneliness feeling

\begin{tabular}{|c|c|c|c|c|c|c|}
\hline \multirow{2}{*}{\multicolumn{2}{|c|}{$\begin{array}{c}\text { Loneliness feeling } \\
\text { Personal characteristics }\end{array}$}} & \multirow{2}{*}{\multicolumn{2}{|c|}{$\begin{array}{c}\text { With loneliness } \\
\text { feeling }\end{array}$}} & \multicolumn{2}{|c|}{ Without loneliness feeling } & $\begin{array}{c}\text { Kind of test and } \\
\text { judgment }\end{array}$ \\
\hline & & & & & & \\
\hline Aqe & Between 60 and 72 & $\frac{\text { Quantity }}{12}$ & $\begin{array}{c}\% \\
85.7\end{array}$ & $\frac{\text { Quantity }}{70}$ & $\begin{array}{c}\% \\
90.9\end{array}$ & \multirow{2}{*}{ Meaningless } \\
\hline & $>72$ to 85 & 2 & 14.3 & 7 & 9.1 & \\
\hline \multirow[t]{2}{*}{ Sex } & Male & 4 & 28.6 & 36 & 46.8 & \multirow[t]{2}{*}{ Meaningless } \\
\hline & Female & 10 & 71.4 & 41 & 53.2 & \\
\hline \multirow[t]{5}{*}{ Marital status } & Single & 1 & 7.1 & 3 & 3.9 & \multirow{5}{*}{$\begin{array}{c}{ }^{* * *} \text { Croxial and Alise test } \\
\mathrm{X}^{2}=9 / 83 \\
\mathrm{df}=3 \\
\mathrm{P}<0 / 02\end{array}$} \\
\hline & Married & 8 & 57.1 & 71 & 92.2 & \\
\hline & Widow & 4 & 28.6 & 2 & 2.6 & \\
\hline & Separated & 1 & 7.1 & 1 & 1.3 & \\
\hline & No & 1 & 7.1 & 16 & 20.8 & \\
\hline \multirow[t]{2}{*}{ Employment } & Yes & 0 & 0 & 11 & 14.3 & \multirow[t]{2}{*}{ Meaningless } \\
\hline & No & 14 & 100 & 66 & 85.7 & \\
\hline \multirow{2}{*}{$\begin{array}{c}\text { The excess income } \\
\text { apart of salary }\end{array}$} & Yes & 0 & 0 & 10 & 13 & \multirow[t]{2}{*}{ Meaningless } \\
\hline & No & 14 & 100 & 67 & 87 & \\
\hline \multirow{2}{*}{$\begin{array}{c}\text { Sufficiency of } \\
\text { income for living }\end{array}$} & Yes & 1 & 7.1 & 5 & 6.5 & \multirow[t]{2}{*}{ Meaningless } \\
\hline & No & 13 & 92.9 & 72 & 93.5 & \\
\hline \multirow{5}{*}{$\begin{array}{l}\text { Who are you living } \\
\text { with? }\end{array}$} & Alone & 6 & 42.9 & 1 & 1.3 & \multirow[t]{4}{*}{ Meaningless } \\
\hline & Spouse & 1 & 7.1 & 21 & 27.3 & \\
\hline & Children & 0 & 0 & 3 & 3.9 & \\
\hline & Spouse and children & 7 & 50 & 50 & 64.9 & \\
\hline & $\begin{array}{l}\text { Other family } \\
\text { members and } \\
\text { relatives }\end{array}$ & 0 & 0 & 2 & 2.6 & Meaningless \\
\hline \multirow{2}{*}{$\begin{array}{l}\text { Satisfaction of the } \\
\text { living environment }\end{array}$} & Yes & 7 & 50 & 56 & 72.7 & \multirow{2}{*}{$\begin{array}{c}\text { Men-vitny you }^{\star * \star *} \\
\mathrm{P}<0.045\end{array}$} \\
\hline & No & 7 & 50 & 21 & 27.3 & \\
\hline \multirow{2}{*}{$\begin{array}{l}\text { Using of the special } \\
\text { medicine }\end{array}$} & Yes & 12 & 85.7 & 40 & 51.9 & \multirow[b]{2}{*}{ Meaningless } \\
\hline & No & 2 & 14.3 & 37 & 48.1 & \\
\hline \multirow{2}{*}{$\begin{array}{l}\text { Do you have } \\
\text { children? }\end{array}$} & Yes & 11 & 78.6 & 72 & 93.5 & \multirow[b]{2}{*}{ Meaningless } \\
\hline & No & 3 & 21.4 & 5 & 6.5 & \\
\hline \multirow{2}{*}{$\begin{array}{l}\text { Do you use the aid } \\
\text { means? }\end{array}$} & Yes & 13 & 92.9 & 61 & 79.2 & \multirow[b]{2}{*}{ Meaningless } \\
\hline & No & 1 & 7.1 & 16 & 20.8 & \\
\hline
\end{tabular}

selected by easy randomized sampling method. The collecting data tools were three questionnaires; the first questionnaire were about the personal and social characteristics of the seniors provided by the researcher were consisted of two parts; the first part contained 20 questions about personal traits and the second part with 11 questions about social characteristics in three fields of the social interactions, participating in social activities and the kind of having social supports such as the support of the unofficial social networks like children, family members, relatives and friends and also the official social networks like complementary insurance organizations and Emdad committee. The second questionnaire was the Allport's intrinsic and extrinsic scales of the religious believes and the third questionnaire was UCLA standardized loneliness scale with 20 questions in four points of never, rarely, sometimes and often.

\section{Findings}

The research findings have been gathered and presented (Tables1-4). The Table 1 and 2 are about frequency distribution of personal and social characteristics consecutively. The Table 3 is about determining the relationship between religious believes Popular article CIndian Society for Education and Environment (iSee) and the personal and social characteristics and the Table 4 is about the determining the relationship between the religious believes and general health in elderly.

Regarding the first and second research objectives, according the Table 1, 90 percent of participants were in the $60-72$ years old group. The average age was 64.65 years old with the deviation of 5.05 years. In this study, 54 percent were female and 45 percent were male. In addition, 86 percent were married and 8 percent were widow. 3 percent were illiterate while the majority $(44 \%)$ had high school diploma, 28 percent with primary school degree, 13 percent high school and 12 percent with higher education. 92 percent had children. 61 percent with spouse and children, 24 percent with spouse, 9 percent alone, 3 percent only with children and 1 percent were living with their sisters and brothers. 88 percent of them were unemployment and only 12 percent were working in the time of study. 92 percent were unhappy about their income and 88 percent didn't have any other source of income except their monthly salary. Regarding the housing, 85 percent had owned their house and 15 percent had rented. 93.8 percent were using glasses and the 6.2 percent were using the other aid means.
"Religion as a tool to overcome the feeling of loneliness in elderly" http://www.indjst.org
F.Sheikholeslami Indian J.Sci.Technol. 
Table 2.Frequency distribution and the relationship between social characteristics and the loneliness feeling

\begin{tabular}{|c|c|c|c|c|c|c|}
\hline \multirow{2}{*}{\multicolumn{2}{|c|}{$\begin{array}{l}\text { Loneliness feeling } \\
\text { Social characteristics }\end{array}$}} & \multicolumn{2}{|c|}{ With loneliness feeling } & \multicolumn{2}{|c|}{ Without loneliness feeling } & \multirow{2}{*}{$\begin{array}{l}\text { Kind of test and } \\
\text { judgment }\end{array}$} \\
\hline & & Quantity & $\%$ & Quantity & $\%$ & \\
\hline \multirow{2}{*}{$\begin{array}{l}\text { Do you visit your } \\
\text { children weekly? }\end{array}$} & Yes & 6 & 54.5 & 54 & 74 & \multirow[t]{2}{*}{ Meaningless } \\
\hline & No & 5 & 45.5 & 19 & 26 & \\
\hline \multirow{2}{*}{$\begin{array}{l}\text { Do you visit your } \\
\text { relatives weekly? }\end{array}$} & Yes & 5 & 35.7 & 41 & 53.2 & \multirow[t]{2}{*}{ Meaningless } \\
\hline & No & 9 & 64.3 & 36 & 46.8 & \\
\hline \multirow{2}{*}{$\begin{array}{l}\text { Do you visit your } \\
\text { friends weekly? }\end{array}$} & Yes & 3 & 21.4 & 28 & 36.4 & \multirow[t]{2}{*}{ Meaningless } \\
\hline & No & 11 & 78.6 & 49 & 63.6 & \\
\hline \multirow{2}{*}{$\begin{array}{l}\text { Do you visit your } \\
\text { neighbors weekly? }\end{array}$} & Yes & 33 & 21.4 & 24 & 31.6 & \multirow[t]{2}{*}{ Meaningless } \\
\hline & No & 11 & 78.6 & 52 & 68.3 & \\
\hline \multirow{3}{*}{$\begin{array}{l}\text { How much do you } \\
\text { enjoy being with } \\
\text { those people? }\end{array}$} & Much & 2 & 14.3 & 25 & 34.2 & \multirow[t]{3}{*}{ Meaningless } \\
\hline & Medium & 7 & 50 & 39 & 53.4 & \\
\hline & Little & 5 & 35.7 & 9 & 2.3 & \\
\hline \multirow{2}{*}{$\begin{array}{l}\text { Do you participate } \\
\text { in social activities? }\end{array}$} & Yes & 1 & 7.1 & 25 & 33.3 & \multirow[t]{2}{*}{ Meaningless } \\
\hline & No & 13 & 92.9 & 50 & 66.7 & \\
\hline \multirow{2}{*}{$\begin{array}{l}\text { Do you participate } \\
\text { in religious } \\
\text { activities? }\end{array}$} & Yes & 9 & 64.3 & 58 & 75.3 & \multirow[t]{2}{*}{ Meaningless } \\
\hline & No & 5 & 35.7 & 19 & 24.7 & \\
\hline \multirow{2}{*}{$\begin{array}{l}\text { Are you supported } \\
\text { emotionally by your } \\
\text { children? }\end{array}$} & Yes & 9 & 64.3 & 62 & 82.7 & \multirow[t]{2}{*}{ Meaningless } \\
\hline & No & 5 & 35.7 & 13 & 17.3 & \\
\hline \multirow{2}{*}{$\begin{array}{l}\text { Are you supported } \\
\text { emotionally by your } \\
\text { relatives? }\end{array}$} & Yes & 3 & 21.4 & 44 & 57.9 & \multirow[b]{2}{*}{ Meaningless } \\
\hline & No & 11 & 78.6 & 32 & 42.1 & \\
\hline \multirow{2}{*}{$\begin{array}{l}\text { Are you supported } \\
\text { emotionally by your } \\
\text { friends? }\end{array}$} & Yes & 3 & 21.4 & 39 & 51.3 & \multirow[t]{2}{*}{ Meaningless } \\
\hline & No & 11 & 78.6 & 37 & 48.7 & \\
\hline \multirow{2}{*}{$\begin{array}{l}\text { Are you supported } \\
\text { emotionally by your } \\
\text { neighbors? }\end{array}$} & Yes & 3 & 21.4 & 33 & 44 & \multirow[t]{2}{*}{ Meaningless } \\
\hline & No & 11 & 78.6 & 42 & 56 & \\
\hline \multirow{3}{*}{$\begin{array}{l}\text { How much do you } \\
\text { satisfy by those } \\
\text { emotional } \\
\text { supports? }\end{array}$} & Much & 2 & 14.3 & 25 & 32.9 & \multirow[t]{3}{*}{ Meaningless } \\
\hline & Medium & 5 & 35.7 & 41 & 53.9 & \\
\hline & Little & 7 & 50 & 10 & 13.2 & \\
\hline
\end{tabular}

To determine the social characteristics of the participants, the study is divided in three parts of; social interactions, participating in social activities and social networks supports (official and unofficial). The information has been summarized in the Table 2. According to this, the 65 percent had weekly visit with children, 50 percent with relatives, 33 percent with friends and 28 percent with neighbors. 68 percent didn't attend in any social activities and only 29 percent were participating in the activities such as attending in Khoshnevisan (good penmanship) association and group physical activities. 79 percent were going to the religious gatherings. The findings have also shown that the majority of the participants, 95percent, didn't have any support from the pervious work place. In response to the question that if there was any facility or entertaining services for their free time in that society, 95 percent answered No. In response to the question if they were supporting by the official social networks such as complementary insurances and Emdad committee, 33 percent of them said Yes. Regarding the kind of social supports from official networks the highest percent of participants (67\%) had not received any kind of supports, 33 percent had financial supports, and 10 percent were supported financially by their children, 3 percent by

Table 3. The correlation between personal - social characteristics and religious beliefs

\begin{tabular}{|c|c|c|c|c|}
\hline Personal and social characteristics & Kind of test & Statistical amount & Amount of $P$ & Test result \\
\hline Sufficiency of income & ***Menvisti you & -3.144 & 0.002 & Meaningful \\
\hline Using the medicine & Menvisti you & -2.261 & 0.024 & Meaningful \\
\hline Visiting the family members weekly & Menvisti you & -2.102 & 0.036 & Meaningful \\
\hline Participating in social activities & Menvisti you & -1.975 & 0.048 & Meaningful \\
\hline Attending in religious gatherings & Menvisti you & -3.142 & 0.002 & Meaningful \\
\hline Family members' emotional supports & Menvisti you & 4.210 & 0.000 & Meaningful \\
\hline Friends' emotional supports & Menvisti you & -2.965 & 0.003 & Meaningful \\
\hline Neighbors' emotional support & Menvisti you & -3.181 & 0.001 & Meaningful \\
\hline Others' emotional supports & Menvisti you & -2.705 & 0.007 & Meaningful \\
\hline Amount of satisfaction of those supports & ${ }^{* * *}$ Croxical and alise & 6.811 & 0.003 & Meaningful \\
\hline $\begin{array}{l}\text { Popular article } \\
\text { (CIndian Society for Education and Environment (iSee) }\end{array}$ & $\begin{array}{l}\text { tool to overcc } \\
\text { http://w }\end{array}$ & $\begin{array}{l}\text { feeling } 0 \\
\text { jst.org }\end{array}$ & & $\begin{array}{l}\text { F.Sheikhole } \\
\text { Indian J.Sci }\end{array}$ \\
\hline
\end{tabular}


family, 6 percent by charities and 3 percent by friends. Regarding the emotional support, the highest percent (76\%) had been received the support by their children

Table 4. Relationship between religious beliefs and loneliness feeling

\begin{tabular}{|c|c|c|c|}
\hline $\begin{array}{c}\text { Loneliness } \\
\text { feeling }\end{array}$ & Quantity & Average of ranks & $\begin{array}{c}\text { Kind of test \& } \\
\text { judgment }\end{array}$ \\
\hline Yes & 11 & 49.36 & \multirow{2}{***}{ Men -vitny $\mathrm{Z}$} \\
Z & 60 & 33.55 & $2.34 ; \mathrm{P}<0.01$ \\
\hline
\end{tabular}

and then consecutively, 51 percent by family members, 44 percent by friends, 38 percent by neighbors and 33 percent by others. The statistical tests regarding the relationship between the religious believes and the personal and social characteristics have been also shown the following results:

There is a meaningful correlation about the sum of the points for religious believes in response to the question that if their income is covering your living costs with the Mann-Whitney test and the $p=0.001$.

There is a meaningful correlation about the sum of the points for religious believes in response to the question that if they participated in social activities such as Khoshnevisan (good penmanship) association, charities and ...with the Mann-Whitney test and the $\mathrm{p}=0.048$.

There is a meaningful correlation about the sum of the points for religious believes in response to the question that if they participated in religious activities such as prayer's meetings, group praying and ...with the Mann-Whitney test and the $p=0.002$.

There is a meaningful correlation about the sum of the points for religious believes in response to the question that if they were received emotional supports by family members, friends and neighbors with the MannWhitney test and the $p<0.001$.

There is a meaningful correlation about the sum of the points for religious believes in response to the question that how much they were happy of the mentioned supports with the Kruskal-Wallis test and the $\mathrm{p}=0.033$.

Regarding the marital status, $57.1 \%$ of married people felt alone and $92.2 \%$ didn't experience it. In widows $28.6 \%$ felt lonely and $2.6 \%$ didn't feel it while $7.1 \%$ of divorced people had the feeling of loneliness and $1.3 \%$ didn't have it. Therefore, the findings indicate that there is a meaningful relationship between the marital status and feeling of loneliness with $p<0.02$. Jones and colleges studied the problem of loneliness in urban and rural general practices. The findings showed that the feeling of loneliness is associated with being widowed, especially in the people who lost their spouse recently. Moreover the elderly lived with spouse or their family felt less lonely than who lived alone or with others except spouse. One of the most important reasons of the aloneness in this study had been the death of spouse which was much less in married people than in other groups (Jones et al., 2009). Social interaction with friends and less with neighbors will decrease the feeling of loneliness and increase the sprite (Lee, 2008).

Regarding the satisfaction of living place, $50 \%$ of people with the positive answer were feeling lonely. There was a meaningful correlation between the loneliness feeling and the satisfaction of living place with $\mathrm{p}<0.045$.

On the subject of social characteristics, in response to the question of being happy of the emotional supports from children, relatives, friends and neighbors, $14.3 \%$ of aged people who had the more satisfaction were feeling lonely and $32.9 \%$ didn't have that feeling, but the statistical analysis revealed no meaningful relationship.

In response to the question of using aid means, $92.9 \%$ of the people who answered positively were feeling lonely and most of them were complaining of visual problems.

Furthermore, the statistical tests regarding the third objective meaning the relationship between the religious believes and the feeling of loneliness have shown a meaningful correlation through the Mann-Whitney test by $\mathrm{p}<0.01$.

\section{Discussion}

Loneliness is considerably related to the gender, marital status, living in special residence, fear and need for help to do daily activities (Jakobsson \& Hellberg, 2005). The findings showed that the feeling of loneliness is associated with being widowed, especially in the people who lost their spouse recently. Moreover, the elderly lived with spouse or their family felt less lonely than who lived alone or with others except spouse. One of the most important reasons of the aloneness in this study had been the death of spouse which was much less in married people than in other groups (Jones et al., 2009). Social interaction with friends and less with neighbors will decrease the feeling of loneliness and increase the sprite (Lee, 2008).

Regarding the second objective, determining the relationship between loneliness feeling and some personal and social characteristics, the findings have been shown that the most amount of loneliness feeling is among elderly between 72 and 85 years old. Various studies have shown that the loneliness feeling will increase with aging. 27 percent of participants between 65 and 69 had experienced the lonesomeness which it was increased to 36 percent for the age above 80 (UNECE, 2003). On the other hand the aging will provide the base for the aloneness. Along with increasing age, different changes will happen in the life of aged people. Income reduction, separation from children, death of loved people and ... all will prepare the appropriate field for the aloneness. Regarding the age also, 71.4 percent of females and 28.6 percent of males were feeling alone. Women generally experience loneliness feeling more than men. Jakobsson and Hellberg (2005) by studying the quality of life, feeling of loneliness and fear among 
Swedish elderly found that loneliness was significantly associated with gender (Jakobsson \& Hellberg, 2005). Also Ekwall, (2005) have shown that the feeling of loneliness was higher among women than men. Besides, the researches' findings have shown that aged women are specifically vulnerable to the loneliness. Holman has related it to the matter women live longer than men. Kim Oksoo and colleges had observed that elderly Korean immigrant women were lonelier (Kim Oksoo, 1999). On the other hand, the feeling of loneliness will get worst by aging and getting far from the stream of life, work, home and family (MODI, 1997).

The researches have been shown that women pay more attention to faith and practicing the religious orders and when they face to any problems, they look for the religious consultations while men will take the religious helps whenever they have very complicated problems (Meisenhelder, 2003). Having more connection with the public entertainment centers and using their facilities have been caused the development of the elderly life and reducing the feeling of isolation and loneliness (MODI, 1997). Dixtera found that the people receiving more emotional supports from their social networks have less feeling of loneliness and the findings revealed that the expanding the social networks will decrease the aloneness (Kim, 1999).

Attending the spiritual (holy) places is not only a source of social support but also it can improve the coping and adjustment mechanisms (Steffen, 2007). Jones (2009) found that there is a meaningful relationship between visual and hearing problems, movement disability and the persistent loneliness feeling. Ghorbanshiroudi et al. (2011) have shown that there is a significant relationship between emotional intelligence and life satisfaction. Communication skill training significantly enhanced the emotional intelligence and life satisfaction. Thus, this study confirms the effectiveness of communication skills in increasing emotional intelligence and life satisfaction.

Researchers have shown that there is a considerable relation between religious believes and spirituality and physical and mental health in elderly which can improve the immune and physiologic responses, increase the physical wellbeing and decrease their mortality (UNECE, 2003) and it is a significantly strong relationship (Steffen, 2007). Motahari and Rahgozar (2011) showed that overall emotional intelligence and its components included skills of problem solving, happiness, independence, resistance to psychological stress, self-flourishing, emotional selfawareness, self-actualization, interpersonal relations, optimism, self-regard, Impulse control, flexibility, social responsibility, empathy, self-assertiveness, flexibility between people with suicide trial record group was lower than normal group. Moreover, this study provides some obvious evidence that $\mathrm{El}$ is a protective role in committing suicide. Therefore, with enhancing emotional components people will be able to decreases the subsequent occurrence of these behavior problems.

Generally, various studies disclosed the relatively high connection between religion and mental health such as reducing the depression feeling, improving the self confidence, developing more support and using the less alcoholic beverage (Koenig et al., 1992). Koenig (2001) in an another study concerning the association among religious believes and practices and mental health and social performances with 850 participants found that religion influences the mental health by empowering the ability of facing to stress, providing the social support atmosphere, developing the hope and being optimistic to improve positive excitements such as better living. In addition, the religious concerns and the related behaviors cause decreasing depression, feeling better and reducing the mortality rate (Lee, 2008). Likewise, Bahrami \& Ramedani (2005) in their study about the effect of religious believes on elderly mental health and depression found that the religious believes are associated with mental health and mental disorders and depression are much higher in seniors who are resident in elderly housing while they have stronger extrinsic religious point of views (Bahrami \& Ramedani, 2005). Khalatbari et al. (2011) indicated that the behavioral cognitive therapy has positive influence over depression of the test group significantly compared to the control group which had received no therapeutic interference. Thus, the behavioral cognitive therapy has been effective on the reduction and elimination of the depression and anxiety in the infertile women.

\section{Conclusion}

This study shows that the internal and external religious beliefs are in a relationship with some of the personal and social characteristics such as attending in the religious gatherings, social activities, and surrounded emotional supports; by improving of those we can have a preventive effect on the loneliness feeling of elderly. Thus, the religious believes, as an important source of support in aged people, can help them to be healthier physically and psychologically and it is essential to consider it for the mental health educational plans.

\section{References}

1. Bahrami F and Ramedani FA (2005) The religious believes in mental health and depression of elderly. Sci. Res. Magazine. Rehabilitation. $6^{\text {th }}$ period, No. 1.

2. Conception MB (2004) Social policy for older person: The Philippine case. Geriatric.Gerontol. Intern. 4(1), S245.

3. Ekwall, Sivberg Hellberg (2005) loneliness as a predictor of quality of life among older caregivers. $J$. Adv. Nurse. 49(1),23-32.

4. Fealy GM (2006) Social capital, age and religiosity in people who are lonely. J. Clini. Nurs. 15(6), 334-340.

5. Ghorbanshiroud S, Khalatbari J, Salehi M, Bahari S and Keikhayfarzaneh MM (2011) The relationship between emotional intelligence and life satisfaction 
and determining their communication skill test effectiveness. Indian J. Sci. Tech. 4(11), 1560-1564.

6. Hellstrom Y, Persson G and Hallberg IR (2004) Quality of life and symptoms among older people living at home. J. Adv. Nur. 48(6), 584-593.

7. Jakobsson $U$ and Hellberg IR (2005) loneliness, fear, and quality of life among elderly in Sweden: a gender perspective. Aging Clin. Exp. Res. 17(6), 494-501.

8. Jones DA, Victor CR and Vetter NJ (2009) The problem of loneliness in the elderly community: characteristics of those who lonely and the factors related to loneliness. JR. Coll. Gen. Pract. 35(272), 136-139.

9. Kagagn $\mathrm{SH}$ (2010). Revisiting interdisciplinary teamwork in geriatric acute care. Geriatric Nurse, Mar 4. 31 (2), 133-136.

10. Khalatbari J, Ghorbanshirodi S, Akhshabi M, Hamzehpour $T$ and Esmaeilpour M (2011) The effectiveness of the behavioral- cognitive therapy on the reduction of the rate of the depression and anxiety of the infertile women of the Rasht city. Indian J. Sci. Technol. 4 (11), 1578-1582.

11. Kim oksoo (1999) Predictors of loneliness in elderly Korean immigrant women living in the United States of America. J. Adv.Nur. 29(5),1082-1088.

12. Koenig HG, Cohen HJ, Blazer DG. 2002. Religious coping and depression among elderly, hospitalized medically ill men. Am. J. Psychiatry. 149, 1693-1700.

13. Koing $\mathrm{H}$ (2001) Handbook of religion and health. New York.Oxford University press.

14. Lee G (2008) Social interaction loneliness and emotional well-being among the elderly. Res.Aging, 9(4), 459-482.

15. Meisenhelder JB (2003) Gender differences in religiosity and functional health in the elderly. Griat Nurs. 24,343-4,352.

16. Motahari AA and Rahgozar S (2011) Inhibitory role of emotional intelligence in committing suicide. Indian Sci. Technol. 4(11),1561-1566.

17. Steffen DC (2007) Spiritual consideration in suicide and depression among the elderly. Southern Med. Asso. 100(7), 211-219.

18. United Nations Economic Commission for Europe (UNECE) (2003) The loneliness of the elderly. Bull. Ageing. pp:3. 